\title{
Penerapan Model Pembelajaran Kooperatif Group Investigation Pada Materi Koperasi SMA Negeri 1 Syamtalira Aron Kabupaten Aceh Utara
}

\author{
Mansur \\ Guru Ekonomi SMANegeri 1 Syamtalira Aron \\ Email : mansurhp68@gmail.com \\ Doi ; 10.32672/jsa.v7i5.1518
}

\begin{abstract}
ABSTRAK
Semakin berkembangnya dunia pendidikan, guru dalam melaksanakan Proses Belajar Mengajar dituntut menggunakan berbagai strategi pembelajaran dan berbagai media yang bervariasi agar mampu mengaktifkan interaksi peserta didik dengan guru, peserta didik dengan peserta didik serta peserta didik dengan lingkungannya. Peran guru bukan satu-satunya sumber ilmu di kelas bergeser menjadi fasilitator bagi peserta didik. Peserta didik, buku-buku pelajaran, jaringan internet, lingkungan sekitar dan teman sejawat untuk dijadikan sebagai sumber belajar. Tujuan penelitian ini adalah untuk meningkatkan ketuntasan belajar peserta didik setelah penggunaan Model Kooperatif Group Investigation serta persentase kemampuan berfikir peserta didik pada materi Koperasi Pelajaran Ekonomi. Prosedur penelitian dilakukan sebanyak dua siklus, dalam setiap siklus terdiri dari empat tahapan, yaitu : perencanaan, pelaksanaan, pengamatan, dan refleksi. Pada tahap observasi dilakukan pengumpulan data dengan melakukan pengamatan terhadap aktifitas peserta didik dan guru dalam proeses belajar mengajar melalui penggunaan Model Kooperatif Group Investigation pada pelajaran ekonomi. Penerapan Model Pembelajaran Kooperatif Group Investigation dapat diketahui bahwa motivasi belajar peserta didik sebesar $72,92 \%$. Hal ini ditunjukkan oleh keaktifan peserta didik dalam mengajukan pertanyaan, menyelesaikan soal dan pengambilan kesimpulan yang menyangkut dengan materi Koperasi. Sedangkan prestasi belajar ditemukan terjadinya peningkatan setiap siklus. Sehingga dapat disimpulkan bahwa Group Investigation dapat meningkatkan ketuntasan belajar siswa dalam materi koperasi.

Kata Kunci : Kooperatif Group Investigation, Hasil Belajar
\end{abstract}

\section{PENDAHULUAN}

Sekolah merupakan wahana untuk dapat mencetak kader generasi yang berkualitas, trampil, inovatif dan kreatif serta mampu bersaing terus seiring perkembangan zaman. Model belajar merupakan suatu sarana yang digunakan seseorang atau kelompok orang untuk menyampaikan pesan, maksud ataupun tujuan kepada orang lain. Menurut Suprijono (2009 : 45-46) model pembelajaran merupakan landasan praktik pembelajaran hasil penurunan teori psikologi pendidikan dan teori belajar yang dirancang berdasarkan analisis terhadap implementasi kurikulum dan implikasinya pada tingkat operasional di kelas. Model juga merupakan sarana untuk dapat menyampaikan sesuatu agar mudah 
dipahami oleh penerima informasi. Oleh karena itu, penggunaan model pembelajaran yang bervariasi memungkinkan peserta didik untuk lebih mudah dalam menerima materi belajar, khususnya pada peserta didik SMA Negeri 1 Syamtalira Aron dalam pelajaran ekonomi.

Tujuan tiap proses belajar mengajar adalah diperolehnya hasil yang optimal. Hal ini bisa dicapai apabila guru dan peserta didik secara langsung aktif baik fisik, mental, dan emosi sesuai dengan pengertian aktifitas belajar yang merupakan keterlibatan peserta didik secara langsung dalam proses pembelajaran. Menurut Sudjana (2010 : 31), secara garis besar membagi hasil belajar menjadi tiga ranah, yaitu ranah kognitif, ranah afektif dan ranah psikomotorik. Penekanan pembelajaran ekonomi lebih diutamakan pada proses dengan tidak melupakan pencapaian tujuan. Kemampuan dan ketrampilan yang dimiliki peserta didik dalam menentukan hasil akhir suatu kegiatan proses belajar mengajar sangat dipengaruhi oleh berbagai faktor. Sardiman (2007 : 39-47) mengemukakan faktor-faktor yang mempengaruhi belajar adalah faktor internal (dari dalam) diri peserta didik dan faktor eksternal (dari luar) peserta didik. Berkaitan dengan factor dari dalam diri peserta didik, selain faktor kemampuan, ada juga faktor lain yaitu motivasi, minat, perhatian, sikap, kebiasaan belajar, ketekunan, kondisi social ekonomi, kondisi fisik dan psikis. Keberadaan faktor psikologis akan senantiasa memberikan landasan dan kemudahan dalam upaya mencapai tujuan belajar secara optimal.

Berdasarkan pengalaman penulis, kebanyakan peserta didik masih memiliki kesulitan dalam perhitungan jasa, baik dalam hal perhitungan maupun dalam menganalisa hasil dari perhitungan jasa (bagi hasil). Rendahnya keaktifan dan hasil belajar peserta didik untuk materi koperasi disebabkan oleh kurang efektifnya pembelajaran dan metode yang diciptakan. Dari pengamatan hasil pembelajaran dan hasil pembahasan soal-soal Ujian Nasional yang menyangkut dengan perhitungan pembagian jasa (bagi hasil) koperasi, peserta didik kelas X.IIS.1 SMAN 1 Syamtalira Aron dapat digambarkan hasil pembelajaran dari aspek Kognitif, 13 orang peserta didik tercapai ketuntasan dan 17 orang peserta didik tidak tercapai ketuntasan. Aspek Afektif 19 orang siswa tercapai ketuntasan dan 11 orang peserta didik tidak tercapai ketuntasan. Aspek Psikomotor (kemampuan menghitung dan menganalisa hasil perhitungan) 10 orang siswa tercapai ketuntasan dan 20 orang peserta didik tidak tercapai ketuntasan. Hal ini dapat disimpulkan berdasarkan hasil peserta didik di atas secara keseluruhan $43,33 \%$ hasil belajar yang tercapai dan 56,67 \% tidak tercapai ketuntasan sesuai dengan nilai KKM yang telah ditentukan. Ini menggambarkan terjadi kesenjangan pada hasil belajar materi Koperasi terutama dalam hal perhitungan sisa hasil usaha (bagi hasil) peserta didik kelas X.IIS.1 SMA Negeri 1 Syamtalira Aron dengan kenyataan hasil pembelajaran. Oleh karena itu perlu adanya solusi berupa strategi pembelajaran yang inovatif sehingga dapat meningkatkan keaktifan dan hasil belajar peserta didik.

Menurut penulis, diantara model pembelajaran yang mampu meningkatkan keaktifan peserta didik adalah model pembelajaran kooperatif group investigation. Isjoni (2007 : 16) mengemukakan cooperative learning, merupakan suatu model pembelajaran yang terpusat kepada peserta didik (student center). Sedangkan Lie (2005 : 28-29) mengemukakan cooperative learning adalah pembelajaran gotong royong yang mana 
Mansur

sistem pembelajarannya member kesempatan peserta didik untuk bekerja sama dengan peserta lain dalam tugas-tugas yang terstruktur (tugas yang telah ditentukan). Slavin (2005 : 215) menyatakan bahwa penggunaan model Group Investigation dapat meningkatkan prestasi belajar peserta didik dan sekaligus dapat meningkatkan hubungan sosial, menumbuhkan sikap toleransi dan mempercayai orang lain. Model ini bertujuan untuk mengarahkan kemampuan peserta didik dalam menganalisis konsep melalui penyelidikan secara mendalam melalui kerja kelompok. Sesuai dengan yang diungkapkan oleh Trianto (2007 : 59), bahwa guru yang menggunakan model kooperatif Group Investigation (GI) umumnya membagi kelas menjadi beberapa kelompok yang beranggotakan 5 sampai 6 peserta didik dengan karakteristik yang berbeda (heterogen). Disamping itu, model group investigation juga menuntut peserta didik agar memiliki kemampuan yang baik dalam berkomunikasi maupun dalam ketrampilan proses kelompok.

\section{METODE PENELITIAN}

Jenis penelitian yang digunakan oleh peneliti adalah Penelitian Tindakan Kelas (PTK) yang terdiri dari tahap, perencanaan, pelaksanaan, pengamatan, dan refleksi. Penelitian ini dilaksanakan di SMA Negri 1 Syamtalira Aron, yang dimulai pada bulan Maret 2018 sampai dengan bulan Mei 2018 yang melibatkan seorang guru untuk menjadi sebagai observer dan 30 peserta didik kelas X.IIS-1 sebagai subjek. Teknik pengumpulan data dalam penelitian ini adalah tes dan lembar observasi. Teknik analisis data yang digunakan adalah deskriptif kualitatif dengan cara mencari nilai rata-rata dan persentase.

\section{HASIL PENELITIAN DAN PEMBAHASAN \\ Diskripsi Siklus I \\ Perencanaan Tindakan I}

Pada tahap perencanaan ini peneliti menyusun Rencana Pelaksanaan Pembelajaran (RPP) dan tes awal dalam materi Koperasi serta lembar observasi. Kemudian menentukan waktu pelaksanaan dan berkonsultasi dengan guru bidang studi sejenis dan kepala sekolah sebagai mitra kesejawatan dalam pelaksanaan pembelajaran melalui penggunaan model pembelajaran kooperatif Group Investigation.

\section{Pelaksanaan Tindakan I}

Mengelola kelas dengan persiapan yang matang, menerapkan dan melaksanakan pembelajaran model kooperatif GI. Pelaksanaan dibagi dalam tiga tahap yaitu : tahap awal, tahap inti dan tahap (kegiatan) akhir.

Tahap awal, meliputi salam pembuka, apersepsi melalui pemberian contoh-contoh sederhana dalam kehidupan dan kemudian pemberian motivasi melalui kegiatan Tanya jawab. Tahap Inti, meliputi penjelasan singkat mengenai koperasi, kemudian peserta didik diminta untuk membentuk kelompok yang terdiri dari lima orang, sekaligus menjelaskan model pembelajaran yang akan diterapkan yaitu model GI. Peserta didik diminta untuk saling berkonsentarsi dan mendiskusikan dalam kelompok atas topik materi yang telah diberikan. Peserta didik yang memiliki kemampuan berfikir lebih baik agar dapat membimbing temannya agar dapat memiliki pemahaman yang sama dalam satu kelompok. Pada saat diskusi berlangsung, guru berkeliling sambil memantau pekerjaan setiap 620 
kelompok dan membantu jika ada kelompok yang mengalami kesulitan dalam menyelesaikan tugasnya. Selanjutnya apabila diskusi dalam kelompok sudah selesai, maka dipresentasikan didepan kelas sesuai dengan waktu yang telah ditetapkan, sementara kelompok yang lain berhak untuk menanggapi dan memberikan sanggahan dan masukan yang membangun. Apabila semua kelompok selesai, maka hasil diskusi untuk kumpulkan. Tahap akhir, meliputi penguatan kembali atas materi yang telah didiskusikan serta pengambilan kesimpulan. Selanjutnya memberikan evaluasi melalui pembagian lembar soal untuk dijawab agar dapat mengetahui tingkat pemahaman peserta didik atas materi yang telah dipelajari. Sesuai terlampir di rencana pembelajaran.

Tabel 1. Hasil Evaluasi, Lembar kerja dan Diskusi Siklus I

SMA Negeri 1 Syamtalira Aron

\begin{tabular}{|c|l|c|c|c|c|c|}
\hline \multirow{2}{*}{ No } & \multicolumn{1}{|c|}{ Kegiatan } & \multicolumn{2}{|c|}{ Nilai } & \multicolumn{2}{c|}{ Persentase } & $\begin{array}{c}\text { Rata- } \\
\text { rata } \\
\text { kelas }\end{array}$ \\
\cline { 3 - 6 } & Tertinggi & Terendah & Tuntas & Tidak & \\
\hline 1. & Evaluasi test & 93 & 54 & $66,67 \%$ & $33,33 \%$ & 67,83 \\
\hline 2. & Lembar kerja P.didik & 90 & 50 & $63,33 \%$ & $36,67 \%$ & 64,90 \\
\hline 3. & Diskusi kelompok & 90 & 57 & $73,33 \%$ & $26,67 \%$ & 70,67 \\
\hline
\end{tabular}

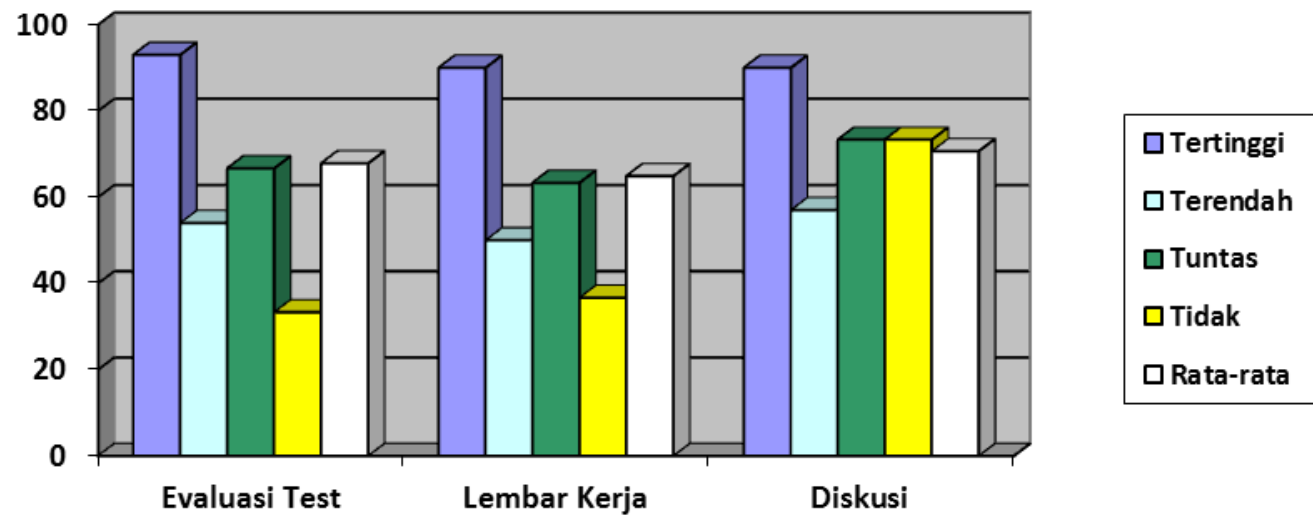

Berdasarkan tabel tersebut, diperoleh hasil nilai rata-rata evaluasi test peserta didik adalah 67,83. Nilai terendah yang diperoleh adalah 54 dan nilai tertinggi adalah 93. Dari hasil ini dapat diketahui bahwa peserta didik yang tuntas sebesar $66,67 \%$ dan yang belum tuntas sebesar 33,33\%. Berdasarkan penjabaran diatas dapat dilihat bahwa nilai rata-rata memang sudah memenuhi KKM, namun kriteria keberhasilan masih kurang. Sementara rata-rata nilai pada kegiatan lembar kerja peserta didik adalah sebesar 70,67. Nilai terendah yang diperoleh adalah 50 dan nilai tertinggi adalah 90, dimana persentase ketuntasan sebesar $63,33 \%$ dan persentase yang belum tuntas sebesar 36,67\%. Berdasarkan penjabaran diatas dapat dilihat bahwa tingkat analisa peserta didik dalam menjawab soal dengan bentuk uraian masih tergolong kurang serta belum menguasai materi yang telah disampaikan. Sedangkan untuk kegiatan diskusi kelompok diperoleh nilai terendah adalah 57 dan nilai tertinggi adalah 90. Dari hasil ini dapat diketahui nilai 
Mansur

rata-rata sebesar 70,67, dimana persentase ketuntasan sebesar $73,33 \%$ dan persentase belum tuntas sebesar $26,67 \%$.

\section{Pengamatan Tindakan I}

Penulis menggunakan guru teman sejawat untuk ikut masuk kelas mengamati kebenaran pelaksanaan pembelajaran yang menggunakan model kooperatif GI. Berdasarkan hasil pengamatan selama kegiatan berlangsung, ditemukan beberapa hal sebagai berikut : (1) Pembelajaran yang dilakukan belum maksimal, karena peneliti belum terbiasa dengan model pembelajaran kooperatif GI ini, (2) Peserta didik memang belum aktif menerima pelajaran dan dalam memberi tanggapan, yang sesuai dengan tujuan model pembelajaran kooperatif GI, (3) Sebagian peserta didik kurang berani berbicara di depan kelas untuk mempresentasikan hasil diskusinya, (4) Pada saat evaluasi tes, peserta didik sudah mulai mengerjakan secara individu meskipun ada beberapa diantara peserta didik yang masih bekerja sama dengan teman yang lain, (5) Untuk sementara, peneliti belum yakin bahwa pelaksanaan supervisi kunjungan kelas akan membantu meningkatkan kemampuan peserta didik, tetapi menurut pemikiran pengamat, cara yang dilakukan peneliti cukup mampu mendorong meningkatkan kreativitas dan prestasi belajar. Selain pengamatan yang dilakukan oleh teman sejawat, upaya lain yang penulis lakukan adalah menyuruh salah satu peserta didik yang pandai untuk mengecek apakah pelaksanaan pembelajaran model kooperatif GI di kelas sudah berjalan sesuai harapan atau belum. Hasil observasi meliputi aktifitas guru dalam mengajar dan aktfitas peserta didik.

Berdasarkan observasi aktifitas guru ditemukan total skor keseluruhan $=44$, sementara skor maksimal $=56$. Sehingga persentase nilai rata-rata adalah $=78,57 \%$, hal ini berarti pembelajaran yang dilakukan oleh guru termasuk dalam katagori "Baik".

Sedangkan observasi aktifitas siswa ditemukan total skor keseluruhan $=37$, sementara skor maksimal $=48$. Sehingga persentase nilai rata-rata adalah $=69,23 \%$, hal ini berarti pembelajaran yang dilakukan oleh guru termasuk dalam katagori "Baik". Namun demikian aktifitas peserta didik masih tergolong rendah terutama dalam hal mengajukan pertanyaan dan memberikan tanggapan atas pertanyaan.

\section{Refleksi Siklus I}

Refleksi dilaksanakan setelah diketahui hasil observasi yang selanjutkan akan diketahu bahwa kegiatan model pembelajaran kooperatif group investigation masih kurang tercapai secara optimal. Hal ini dapat diketahui dari catatan lapangan antara lain ; pada saat guru menjelaskan aturan main, sebagian peserta didik mulai gaduh karena mereka tidak suka berkelompok secara heterogen dengan sistem acak, mereka lebih senang berkelompok sesama taman akrabnya masing-masing.

\section{Diskripsi Siklus II \\ Perencanaan Siklus II}

Perencanaan pembelajaran yang perlu diterapkan pada siklus II antara lain : a) Peneliti merencanakan kembali jadwal untuk melakukan pembelajaran di kelas dengan submateri perhitungan Sisa Hasil Usaha (SHU) koperasi, b) Menyusun RPP yang baik sesuai model pembelajaran kooperatif GI serta membuat instrumen pengumpulan data 
yaitu tes prestasi belajar yang lebih menarik yang akan dikerjakan secara berkelompok untuk membangun kerjasama dalam diskusi kelompok. Memberikan pertanyaan bagi peserta didik atau kelompok yang masih pasif dan memberikan penghargaan khusus bagi peserta didik yang aktif dalam pembelajaran sebagai penyemangat dalam kegiatan pembelajaran, c) Membuat soal evaluasi tes yang menyenangkan untuk mengkur sejauh mana pemahaman peserta didik terhadap materi yang telah diajarkan. Evaluasi ini sesuai dengan refleksi pada siklus I sehingga peserta didik dapat mencapai ketuntasan belajar secara maksimal, d) Bersama guru merancang skenario penerapan pembelajaran dengan melihat kekurangan-kekurangan yang ada pada siklus I dengan mengidentifikasi hal-hal yang bisa dilakukan untuk peningkatan pembelajaran. Untuk hal ini, semua catatan tentang kekurangan yang ada di siklus I yang merupakan hasil refleksi disampaikan pada guru untuk dipelajari. Memberitahu guru apa-apa yang perlu dilaksanakan, apa saja yang peserta didik mesti kerjakan, cara penerapan Model kooperatif GI yang benar sesuai kebenaran teori yang disampaikan.

\section{Pelaksanaan Tindakan Siklus II}

Pada hari yang sudah ditentukan sesuai jadwal, peneliti memulai tahap pelaksanaan tindakan dengan membawa semua persiapan yang sudah dibuat. Sesuai dengan perencanaan yang telah disusun dalam bentuk rancangan pembelajaran dengan penerapan model pembelajaran kooperatif Group Investigation. Adapun langkah-langkahnya sebagai berikut:

Langkah pertama, melaksanakan kegiatan awal berupa berdo'a dan apersepsi siswa. Sebelum menjelaskan kompetensi dan tujuan pembelajaran yang harus dicapai, guru kembali mengingatkan kembali materi yang telah dipelajari sebelumnya kemudian dilanjutkan dengan mengingat kembali aturan main dalam pembelajaran kooperatif group investigation. Selain itu guru juga memberikan contoh sederhana dalam kehidupan seharihari berkaitan dengan materi koperasi. Langkah selajutnya, sebagai kegiatan inti, dimana guru menjelaskan materi lanjutan dari koperasi berupa cara menghitung sisa hasil usaha (bagi hasil). Selesai dari penjelasan singkat serta contoh dari perhitungan sisa hasil usaha (bagi hasil), guru meminta peserta didik untuk membentuk kelompok secara heterogen. Kemudian menjelaskan kembali secara singkat aturan dalam pembelajaran kooperatif model group investigation. a). Semua peserta didik yang telah dibagi oleh guru supaya dapat berkumpul dalam kelompok masing-masing. b). seiap kelompok diberikan tugas yang menyangkut perhitungan sisa hasil usaha (bagi hasil) untuk diselesaikan secara berdiskusi dalam kelompok masing-masing, sementara guru berkeliling untuk memantau dan memberikan bimbingan bagi kelompok yang merasa kesulitan. c). setiap peserta didik diberikan hak yang sama dalam forumnya masing-masing untuk mengeluarkan pendapat sesuai dengan materi diskusi, dimana sebagian besar mereka sudah mampu mendengarkan dan mengajukan pendapat dalam kelompoknya. d). Peserta didik yang telah memahami agar dapat memberikan penjelasan kepada teman yang belum memahami dalam satu kelompoknya. e). Apabila diskusi tiap kelompok sudah selesai, diharapkan untuk dapat dipresentasikan di depan kelas, sementara kelompok yang lain menanggapi, member saran, sanggahan ataupun pertanyaan sesuai dengan materi bahasan kelompok tersebut. 
Mansur

Langkah terakhir, pada tahap akhir setelah diskusi selesai kemudian diadakan evaluasi tes siklus II. Guru memberikan lembar soal dan lembar jawaban kepada setiap peserta didik. Dalam mengerjakan soal tersebut, peserta didik diminta untuk dapat menyelesaikan secara tertib dan secara pribadi sesuai dengan waktu yang telah ditetapkan. Selanjutnya selesai mengerjakan soal sebagai evaluasi tes guru meminta untuk mengumpulkan lembar kerja yang telah dibagikan.

Tabel 2. Hasil Evaluasi, Lembar kerja dan Diskusi Siklus II

SMA Negeri 1 Syamtalira Aron

\begin{tabular}{|c|l|c|c|c|c|c|}
\hline \multirow{2}{*}{ No } & \multicolumn{1}{|c|}{ Kegiatan } & \multicolumn{2}{|c|}{ Nilai } & \multicolumn{2}{c|}{ Persentase } & Rata- \\
\cline { 3 - 6 } & & Tertinggi & Terendah & Tuntas & Tidak & $\begin{array}{c}\text { rata } \\
\text { kelas }\end{array}$ \\
\hline 1. & Evaluasi test & 98 & 60 & $83,33 \%$ & $16,67 \%$ & 73,03 \\
\hline 2. & Lembar kerja P.didik & 92 & 57 & $73,33 \%$ & $26,67 \%$ & 71,27 \\
\hline 3. & Diskusi kelompok & 96 & 59 & $93,33 \%$ & $06,67 \%$ & 75,50 \\
\hline
\end{tabular}
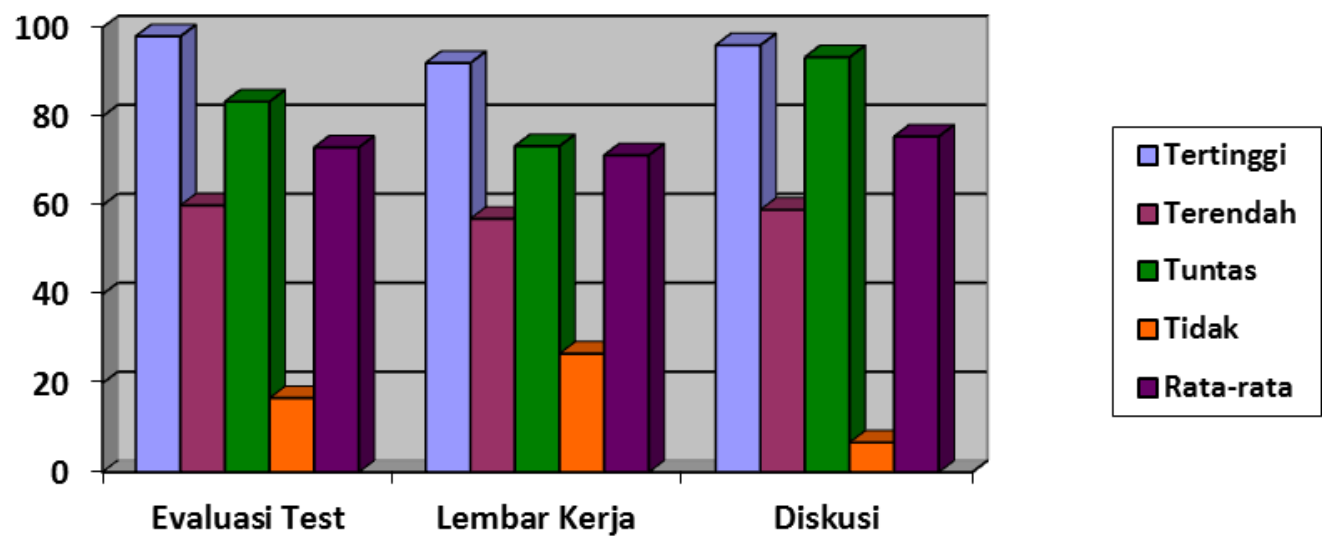

Berdasarkan keterangan tabel diatas dengan membandingkan antara teori dengan hasil yang sesungguhnya dapat ditarik kesimpulan bahwa nilai rata-rata kelas X.IIS-1 telah memenuhi Kriteria Ketuntasan Minimum (KKM) yaitu sebesar 62,00\% dan termasuk dalam kriteria baik karena ketuntasan peserta didik pada evaluasi tes mencapai 83,33\% dari keseluruhan peserta didik. Dari data tersebut, diketahui bahwa persentase ketuntasan masih rendah pada kegiatan lembar kerja, hal ini dapat dilihat pada tingkat analisis peserta didik dalam menjawab soal dengan bentuk uraian. Namun demikian pada siklus II ini telah terjadi peningkatan jika dibanding dengan siklus I, sehingga dapat disimpulkan bahwa tingkat analisis peserta didik dalam menjawab soal bentuk uraian tergolong sangat baik.

Kegiatan diskusi kelompok sudah berjalan dengan baik sekali, sebagian besar peserta didik berpartisipasi aktif dalam kegiatan masing-masing kelompoknya. Hal ini dapat dilihat pada hasil diskusi dari masing-masing kelompok. Nilai-nilai yang diperoleh peserta didik dengan nilai rata-rata kelas sebesar 75,40\%.

\section{Pengamatan Siklus II}

Penilaian terhadap kebenaran pelaksanaan pembelajaran model kooperatif group investigation didahului dengan mencatat hal-hal penting seperti aktivitas belajar yang 
dilakukan pada saat peneliti melakukan tindakan. Dari catatan-catatan yang cepat tersebut penulis mengetahui bagian mana yang mesti diperbaiki, dibagian mana diperlukan penekanan-penekanan, dibagian mananya perlu diberi saran-saran serta penguatanpenguatan. Di samping itu adanya guru yang mengamati proses pembelajaran akan sangat membantu untuk mengetahui kesalahan-kesalahan yang dilakukan selama proses pembelajaran. Guru yang mengamati mencatat juga kreativitas peserta didik, kemauan peserta didik untuk ikut berpartisipasi dalam pembelajaran, kontribusi diantara para peserta didik. Semua ini sudah terlaksana dengan baik.

Hasil observasi meliputi aktifitas guru dalam mengajar dan aktfitas peserta didik dalam pembelajaran. Analisis data hasil observasi menggunakan analisis persentase. Hasil dari kedua observasi dapat diketahui bahwa total skor keseluruhan $=42$, sementara skor maksimal $=52$. Sehingga persentase nilai rata-rata adalah $=80,77 \%$, hal ini berarti pembelajaran yang dilakukan oleh guru termasuk dalam katagori "Baik". Sekaligus mengalami peningkatan persentase aktifitas guru dalam pembelajaran sebesar $5,77 \%$ dari siklus I.

Hasil analisis aktifitas peserta didik ditemukan total skor keseluruhan $=35$, sementara jumlah skor maksimal $=48$. Sehingga persentase nilai rata-rata adalah $=$ $72,92 \%$, hal ini berarti pembelajaran yang dilakukan oleh guru termasuk dalam katagori "Baik". Sekaligus mengalami peningkatan persentase sebesar 4,17\% dari siklus I.

\section{Refleksi Siklus II}

Pada siklus ini sudah terlaksana cukup optimal, ini terlihat dari kegiatan diskusi kelompok yang sudah hidup. Dari aspek evaluasi tes persentase ketuntasan mengalami peningkatan dari $66,67 \%$ pada siklus I menjadi 83,33\% pada siklus II. Untuk aspek lembar kerja peserta didik anggota kelompok juga terjadi peningkatan, hal ini bisa dilihat dari persentase nilai ketuntasan yang diperoleh mengalami peningkatan dari 63,33\% pada siklus I menjadi 73,33\% pada siklus II. Dari aspek diskusi motivasi dan partisipasi setiap anggota kelompok terlihat sangat antusias, hal ini bisa dilihat dari persentase nilai ketuntasan yang diperoleh mengalami peningkatan dari $73,33 \%$ pada siklus I menjadi 93,33\% pada siklus II. Dari ketiga aspek tersebut tercermin bahwa kesiapan mereka untuk diskusi mereka sangat bersemangat, hal ini terjadi karena mereka sudah merasa senang dengan model pembelajaran kooperatif GI juga didukung juga pemberian penghargaan dari guru. Selain itu pada tahap penghargaan, mereka sangat antusias memperhatikan skor peningkatan yang mereka peroleh dengan saling menggoda dan memberikan semangat ketika mengetahui kelompok mana yang memperoleh gelar yang telah mereka siapkan.

\section{PENUTUP}

\section{Simpulan}

Dari hasil analisis data dan pembahasan pada penelitian ini diketahui bahwa pemicu rendahnya aktivitas belajar dan prestasi belajar ada pada faktor-faktor seperti media, model pembelajaran yang digunakan guru, sehingga penggunaan atau penggantian model konvensional menjadi model yang sifatnya konstruktivis sangat diperlukan, akibatnya peneliti mencoba model pembelajaran kooperatif group investigation (GI) 
Mansur

dalam upaya untuk dapat memecahkan permasalahan yang ada di sekolah terutama dalam hal peningkatan hasil belajar (prestasi). Berdasarkan pada rendahnya aktivitas belajar dan hasil belajar (prestasi) belajar peserta didik yang disampaikan pada latar belakang masalah, penggunaan model pembelajaran kooperatif group investigation diupayakan untuk dapat menyelesaikan tujuan penelitian ini yaitu untuk mengetahui peningkatan hasil belajar (prestasi) peserta didik. Seberapa besar peningkatan yang dicapai sudah dipaparkan dengan jelas pada akhir analisis. Dari hasil penelitian yang disampaikan di Bab IV dan semua data yang telah disampaikan tersebut, tujuan penelitian yang disampaikan sudah dapat dicapai.

Proses penerapan model pembelajaran kooperatif group investigation pada materi koperasi terbukti dapat meningkatkan keaktifan dan hasil belajar peserta didik kelas X.IIS1 SMA Negeri 1 Syamtalira Aron. Hal ini dibuktikan dengan nilai rata-rata evaluasi tes kelas X.IIS-1 dimana pada siklus I sebesar 69,03\% dan sebesar 82,03\% pada siklus II terjadi peningkatan sebesar $13,00 \%$. Nilai rata-rata lembar kerja kelas X.IIS-1 dimana pada siklus I sebesar $67,53 \%$ dan sebesar 80,53 pada siklus II terjadi peningkatan sebesar 13,00\%. Nilai rata-rata diskusi kelompok kelas X.IIS-1 dimana pada siklus I sebesar $74,00 \%$ dan sebesar $86,50 \%$ pada siklus II terjadi teningkatan $12,50 \%$. Lembar pengamatan aktifitas guru dan aktifitas peserta didik jugan mengalami peningkatan, hal ini dapat dilihat pada pengamatan siklus I dan pengamatan siklus II. Pada siklus I persentase aktifitas guru sebesar 75,00\% dan pada siklus II sebesar 80,77\%, hal ini berari terjadi peningkatan sebesar 5,77\%, Sementara aktifitas peserta didik pada siklus I sebesar $68,75 \%$ dan pada siklus II sebesar 72,92\%, hal ini berari terjadi peningkatan sebesar 4,17\%.

\section{DAFTAR PUSTAKA}

Isjoni. 2009. Cooperative Learning Mengembangkan Kemampuan Belajar Berkelompok. Bandung : Alfabeta.

Lie, Anita. 2005. Mempraktekkan Cooperative Learning di Ruang-ruang Kelas. Jakarta: Grasinda

Trianto, 2007. Model-model Pembelajaran iInovatif berorientasi kontruktivistik. Jakarta: Prestasi Pustaka.

Sardiman, Arief. 2007. Interaksi dan Motivasi Belajar Mengajar. Jakarta : Rajawali Pers.

Suprijono, Agus. 2009. Cooperative Learning: Teori dan Aplikasi PAIKEM. Yogyakarta : Pustaka Pelajar.

Slavin. Robert E. 2005. Cooperative Learning. Bandung : Nusa Media.

Sudjana, Nana. 2009. Penilaian Hasil Proses Belajar Mengajar. Bandung : Remaja Rosdakarya. 